See discussions, stats, and author profiles for this publication at: https://www.researchgate.net/publication/233036690

\title{
The pinto legacy: The community as an indirect victim of corporate deviance
}

Article in Criminal Justice Studies · February 2000

DOI: 10.1080/1478601X.2000.9959551

CITATIONS

2

3 authors:

1. Paul J. Becker

University of Dayton

11 PUBLICATIONS 57 CITATIONS

SEE PROFILE

Alan S. Bruce

Quinnipiac University

3 PUBLICATIONS 13 CITATIONS

SEE PROFILE

Some of the authors of this publication are also working on these related projects:

Reviews View project

Project State of Indiana vs Ford Motor Company Case View project
18 PUBLICATIONS 61 CITATIONS

SEE PROFILE 


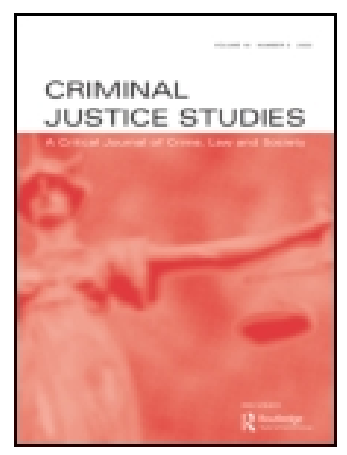

\section{The Justice Professional}

\section{The pinto legacy: The community as an indirect victim of corporate deviance}

\section{Paul J. Becker , Arthur J. Jipson \& Alan Bruce}

To cite this article: Paul J. Becker , Arthur J. Jipson \& Alan Bruce (2000) The pinto legacy: The community as an indirect victim of corporate deviance, The Justice Professional, 12:3, 305-326, DOI: 10.1080/1478601X.2000.9959551

To link to this article: http://dx.doi.org/10.1080/1478601X.2000.9959551

\section{Published online: 23 Apr 2010.}

Submit your article to this journal ¿

Џ Article views: 61 


\title{
THE PINTO LEGACY: THE COMMUNITY AS AN INDIRECT VICTIM OF CORPORATE DEVIANCE
}

\author{
PAUL J. BECKER ${ }^{\mathrm{a}, *}$, ARTHUR J. JIPSON ${ }^{\mathrm{b}}$ and ALAN BRUCE ${ }^{\mathrm{c}}$ \\ ${ }^{\mathrm{a}}$ Rader Hall 347, Department of Sociology, \\ Morehead State University, Morehead, KY 40351; \\ ${ }^{\mathrm{b}}$ Miami University; ${ }^{\mathrm{c}}$ Keuka College
}

In 1978, in Elkhart County Indiana, three teenage girls died following an "accident" in which their Ford Pinto was struck from behind and burst into flames. Two years later, in what has been described as a landmark case (Maakestad, 1987; Clinard, 1990; Frank and Lynch, 1992; Hills, 1987), a trial began in which the Ford Motor Company, as a result of this incident, found itself facing three charges of reckless homicide (State of Indiana v. Ford Motor Company, hereafter referred to as the Pinto Case). While this was not the first time an automobile manufacturer was faced with a potentially lethal faulty design (the Chevrolet Covair among others), it was the first case to result in a criminal homicide charge. The Pinto case has received considerable attention in the criminological and legal literature, ranging from journal articles (Clark, 1979; Swigert and Farrell, 1980-81; Wheeler, 1981), to discussions in textbooks (Albanese, 1995; Green, 1997), to books focusing on the case in varying degrees (Birsch and Fielder, 1994; Cullen et al., 1987; Strobel, 1980; Welty, 1982).

Keywords: State of Indiana v. Ford Motor Company (Pinto Case); corporate deviance; conceptualization of victimization; long term impact

\section{INTRODUCTION}

The purpose of this study was two-fold. The first goal was to return to Northern Indiana to examine the long term impact this incident may have had on residents of the area. We hypothesized that the publicity and dramatic nature of the case would produce some community response to the event. An additional goal was to begin developing a theory of the Indirect victimization of communities by corporate deviance. What, if any,

\footnotetext{
*Corresponding author. E-mail: p.becker@morehead-st.edu.
} 
effect does dramatic criminal events have on communities? Are actors in the community shaped by these events? If so, in what ways are they influenced? If not, what accounts for the insulation of the community from these events? Are communities victimized by traumatic criminological events similarly to individuals? We have conceptualized victimization as occurring on five different levels when considering the impact of criminal events:

Level I-The Immediate Victim-this is the only level in which there is a Direct Victim, the remaining levels are all indirect victims. This represents the common perception of victims as individuals who are responding and interacting to offender(s).

Level II-Family of the Victims - this level represents the impact of the interaction between the victim with significant others in their immediate home environment.

Level III-Friends of the Victims-the consequences of the offense on friends and acquaintances of the victim.

Level IV-Associates of the Victims-the impact of the offense and victimization through one's social networks, e.g., work, school, church, and other important institutions and groups.

Level V-The Community as Victim-the affects of the victimization upon the larger community where the offense takes place.

It is the fifth level, the community as a victim, which we are interested in exploring. By taking a specific incident, we are able to see whether communities suffer long term consequences, as indirect victims, from an incident of corporate crime or malfeasance which occurred there. In the Ford Pinto case, it is an alleged criminal incident as the trial resulted in an acquittal; however, it is important to keep in mind that an acquittal does not necessarily equate innocence. We believe that such incidents may carry long term consequences for the community in which they occur. In the Pinto trial, following the verdict, some jurors "[s]aid they did not believe the Pinto was a safe car, but Michael Cosentino, Elkhart County Prosecutor, did not present sufficient evidence to convict Ford" (Schreiber, 1980). The jury foreman gave one reason for this when he commented that "[a] few jurors felt 'they were a little shortchanged' in the amount of evidence [the judge] let them see" (Strobel, 1980). In addition, the authors believe that it is an appropriate case study due to the attention the trial receives in the criminology and legal literature. 
Data were gathered using a variety of techniques: In-depth personal interviews with community members and actors involved in the case, archival research, and qualitative content analysis of local print news coverage of the incident and trial. Before going into detail about this study, we will briefly outline some of the events related to the case and background information on the community being studied.

\section{THE PINTO CASE AND THE COMMUNITY}

A brief outline of the events and descriptions of the communities involved are necessary to understand the scope of this study. This project focuses on controversial events within a geographical "community" of Northern Indiana. We use the term "community" to refer to the relations and attachments among members of this part of Indiana. A form of social bonding is crafted out of the experience of living in proximity and by living and working in a similar area, a sense of connection is maintained. We assert that people living in a geographically contiguous area have the potential of creating meaningful social relationships over time. So, for the purposes of this study, a community is a group of people who may have in all likelihood never met face-to-face, but who interact in the area in which they live, make linkages and relationships with some of their neighbors, and experience some degree of solidarity. We believe that an incident like the tragedy that occurred to the Ulrich girls, who were in the Pinto when it exploded, should resonate across a community. It is our contention that the nature and outcome of the incident should provoke strong reactions among community members and that this response demonstrates the degree of cohesion in the community.

The accident, which led to the Pinto trial, occurred on August 10, 1978 on U.S. 33 in Elkhart County, Indiana when a van, driven by Richard Duggar, struck a Ford Pinto in a rear-end collision. Just prior to the impact Duggar had reached down for a cigarette, which had fallen to the floor, and when he looked up it was too late to avoid the collision. According to witnesses, the Pinto burst into flames killing two of the three female passengers, with the third dying at a later time. Two of the girls, Judy and Lyn Ulrich, were from the small town of Osceolo Indiana located in neighboring Saint Joseph County, and the third victim, their cousin Donna, was from Illinois. Cullen et al. (1987, p. 175) provided a description of 
Elkhart County at that time of the accident:

Its population of over 125,000, including the city of Elkhart with about 45,000 is composed of typical "middle Americans." Conservatives outnumber liberals by over two to one ... because of the strong Mennonite and Amish heritage in the region, religion continues to flourish, often with a fundamentalist flavor. Elkhart residents are proud that the county is the "mobile-home capital of the world" and that a number of self made millionaires were born, raised, and live in Elkhart ...

On September 13, 1978 a grand jury, convened by Elkhart County prosecutor Michael Cosentino, returned a three count indictment of reckless homicide against the Ford Motor Company. There were other possible targets for placing blame including Richard Dugger, who was twenty-one and already had his license previously suspended. In addition, at the time of the accident located in his van were two empty beer bottles, five grams of marijuana, and pills, which were initially thought to be amphetamines but later identified as caffeine pills. Tests later showed that Dugger was not under the influence of drugs or alcohol at the time of the accident. There were also those who claimed responsibility should lie with the Indiana Highway Department and the engineers who designed the road. U.S. 33 had eight inch high curbs running the length of the road with no shoulder or space for emergency stops. In fact, "[t]he curbed shoulderless road was so dangerous that the Elkhart County Citizens' Safety Committee has written a letter to the Indiana State Highway department asking that the roads be modified to provide safe stopping spaces for emergencies." (Wheeler, 1981, p. 251). The grand jury also recommended that the curbs be removed and this was done within a year. Even with the possible attribution of responsibility toward others, the case was continued against Ford. Following the indictment, a change of venue was granted and the trial was moved fifty miles away to Winamac Indiana located in Pulaski County. On March 13, 1980, following a trial lasting ten weeks, the jury returned not guilty verdicts on all three counts. While, the case has received a great deal of attention and scrutiny, the issue of victimization by corporate actors has not. Thus, we next discuss the relationship between victimology and corporate crime.

\section{VICTIMOLOGY AND CORPORATE CRIME}

The literature on corporate crime has examined a variety of issues including the decision-making process in determining to prosecute these offenses 
(Ayers and Frank, 1987; Benson et al., 1988; 1990), and questions on liability (Fischel and Sykes, 1996; Lansing and Hatfield, 1985; Nagel and Hagan, 1982; Podgor, 1994; Tigar, 1990). There is also work which has focused on specific populations, such as female victims of corporate crime (Szockyj and Fox, 1996) as well as case studies looking at the immediate and direct costs of specific instances of corporate crime (e.g., Geis et al., among others, in Geis et al., 1995). Research has also been conducted into the overall costs of white collar crime. Moore and Mills (1990) discuss three areas where the secondary impact of white collar crime has been identified (1990, p. 414): "(a) diminished faith in a free economy and in business leaders, (b) loss of confidence in political institutions, processes, and leaders, and (c) erosion of public morality" (For a discussion on the harms of corporate crime see Stitt and Giacopassi 1995; and for a more general discussion on the consequences of white collar crime see Meier and Short, 1995).

One area that the victimology literature is lacking is in providing an analysis on the effect that corporate offenses have on the victims. Moore and Mills (1990, p. 408) comment on this void: "[v]ictimization researchers and the victims movement have ignored entirely the victims of white-collar crime," a category which includes corporate crime, though recent research has begun to fill the void concerning white collar crime (see Shover et al., 1994). Shover et al. (1994) state that "[c]ertain categories of white-collar crime-such as environmental devastation and disasters resulting from corporate negligence or malfeasance--might tend especially to generate long-term effects of victimization." Perhaps, the closest discussion of community as victim is Erickson's exceptional Everything in its Path (1976), which presents a detailed description of the impact of a corporate-created flood disaster on several West-Virginian coal-mining communities. While we concede the death of three girls in Indiana is far from a "natural disaster," we note that this type of incident may also generate long-term effects of victimization. It is possible that the attention that this tragedy would engender could leave a lasting impact on the community. Geis (1975, p. 95) also points out that more attention is needed in the "[d]eath dealing consequences of white-collar crime", which once again would include the Pinto case.

The aim of the present study is in examining the long term impact of corporate crime because there has been little work in this area (Albanese 1984 examines the legal legacy of Love Canal). Even rarer is research examining the long term consequences on larger collectives such as 
communities, although Meyer (1981) discusses communities as victims of corporate crime, he focuses on direct victimization where the victims can be clearly identified. Identification of victims of corporate and white collar crime may not be so easily discerned. Burt (1997, p. 6) states that "[a]s we try to understand the impacts of crime to people other than the immediate victim, the prospect becomes more complicated and the research gets thinner." The author discusses the impact on relationships, families and friends, then adds "[w]e have even less information, or techniques, for assessing the impact of crime on whole communities." Though much of these discussions concern interpersonal violence, we feel the same arguments can be extended to corporate crime. Lynch $(1997$, p. 5) adds "[t]he need for greater attention to the victimization of collectives. This includes both the examination of the effects of criminal acts on collectives such as families, organizations, neighborhoods, and communities and also giving priority to crimes by virtue of their effects on collectives." Gulotta (1995) also discusses collective victimization and finds evidence for the existence of indirect victimization (1995, p. 714). We plan to address victimization at the level of community by examining the degree and kind of consequences of the well known State of Indiana v. Ford Motor Company case, known colloquially as "the Pinto case," on the local community.

The community of greater Elkhart is the perceived victim for this study because the girls were killed via the accident in this area. We were unable to locate any family members of the victims and decided that it was unnecessary. The primary reason for this is that we are not interested in personal victimization, but the notion of community as victim and the girls lived outside of Elkhart County. The community is also viewed as the victim because the original impetus from the prosecution to indict Ford for reckless homicide stemmed from this community. Legally, this would imply that in the mind (and actions) of the prosecutor's office, the community as a whole was victimized by Ford's construction and selling of a defective auto. According to Frank and Lynch (1992) "The prosecution of this case acted as a marker of moral indignation, and indicated that the community will not tolerate such behavior" (1992, p. 42). These factors would make Elkhart County an indirect victim, unlike cases such as Love Canal where it is clear that the community suffered direct consequences based on the actions of a corporation.

The objective of this research is to fill the void in the literature dealing with the long term consequences of corporate crime, specifically the 
effects on residents who are indirect victims, in communities where incidents occurred. In this study the focus is on the consequences of the trial. An argument may be made to examine the consequences of the act (e.g., the accident) yet had Cosentino not sought an indictment against Ford, it appears as if the community may have viewed it as just another accident; therefore, it is the indictment and prosecution that deserves attention in this case.

\section{METHODOLOGY}

This research is a single case study of a series of past events. A case study is a form of research that emphasizes the unique history and context of a case (Platt, 1984; Stoecker, 1991). Case studies are "those research projects which attempt to explain holistically the dynamics of a certain historical period of a particular social unit" (Stoecker, 1991, pp. 97-8). The case study creates a frame that determines the boundaries of the data collection (Stoecker, 1991, p. 101). As Becker (1966) argued, the case study is first and foremost a cultural examination process. Such a process forces the researcher to consider the object under study as a totality. The " "process' is both historical and idiosyncratic" (Stoecker, 1991, p. 94) which attests to the strength of the case study in examining past litigation and its impact. This approach allows us to investigate the case while evaluating the victimology literature.

This work utilizes an integrated multiple methodological approach. The various forms of data retrieval to be pursued in this research are: (1) victimology and corporate crime literature review, (2) personal interviews, and (3) qualitative content analysis of news sources. It is believed that a multifaceted approach allows for the largest acquisition of relevant information.

One of the primary methods used in this research was an examination and evaluation of relevant literature and materials on victimology and corporate crime. The decision as to what constitutes relevant material is vested in terms of what can assist in understanding the impact of the Pinto case on the local community, especially Elkhart County where the incident occurred.

Another important form of literature review for this study is news sources. One of the major sources of articles was a four volume set, collected from the local and national print media, given to all members of the prosecution team and lent to the authors by Bruce Berner. In addition, the 
collections of Marvin Riecksecker and the Elkhart Public Library proved to be very valuable. A review of newspaper and news magazine accounts that describe the events and activities that led to the decision to prosecute was conducted. This review was concerned with the community's reaction and perception of the case against the Ford Motor company. While the manner in which such reporting is done is currently a concern, this is not the focus here. The authors were particularly interested in the discussions of the actors, chronologies, and rationales for the events and activities that surrounded the decision to prosecute.

In-depth personal and telephone interviews were focused on a relevant series of questions (see Appendix A for a listing of interview questions) that examine the ideas, perceptions, and events that surround the case. Follow-up interviews were conducted as other relevant questions arose during the transcription and elaboration process. In other words, most respondents were interviewed once and a few individuals were subjected to follow ups. The rationale for a second interview was the need for additional information or to elicit a response to new information. Most of the interviews were taped, except where permission was not granted, and then later transcribed.

Subjects interviewed included members of the defense and prosecution, reporters who covered the case, community members, and members of area Ford dealerships. A snowball sample was used because through contact with relevant individuals and content analysis of previous works on the case more subjects could be added to the list of interviews. A snowball sample is based on the premise that if you wish to learn the patterns of an organization or event, you begin by interviewing subjects who are close at hand, asking them who they would consider essential interviewees, and then attempting to contact these people. Thus, at the beginning of the research there is no established number of individuals that the researcher must contact. A potential problem is that the researcher will only hear people of a similar mind set. To offset this, the author's goal was to interview people on all sides of the Ford Pinto case.

The criterion for recruitment was simply participation or involvement in the case. Thus, recruitment focused on individuals who live in the area and outside the region. Professionals (lawyers, professors, solicitors) who had extensive dealings with any of these individuals or organizations were also relevant to the topic at hand. After initial "cold calls" a snowball method was used to increase and expand the sample, using the same approach, same questions, and same consent form. 
To examine the impact on residents the target population was individuals who were at least in their teens and living in Elkhart County at the time of the accident. This presented some methodological problems in locating this specific population. In July, The Elkhart Truth ran a brief story about this project requesting that any individual living in Elkhart County at the time who would be willing to participate in a focus group or to complete a questionnaire contact the authors (see Lee, 1993 for a discussion on using the media to recruit subjects); however, in this case the method generated no responses. A snowball sampling technique generated eleven complete surveys (see Appendix B), with thirty-eight individuals declining to complete the survey because they could not recall the incident in any detail. All subjects lived in the city of Elkhart at the time of the incident and trial; seven were female; and subjects ranged from 33-80 years of age. Finally, several informal conversations were held with residents and one in-depth personal interview was completed. While we realize that generalizations can not be made, due to sampling limitations, we feel that this research can provide an indication as to community attitudes which will be useful in developing future research.

A point that needs to be made is that one of the researchers is originally from the community to be studied and was living there during the incident in question. By utilizing additional researchers the issue of bias should be eliminated. On the other hand, there are advantages to having a researcher from within the community. The first is that the researcher worked as a probation officer for three years in Elkhart and this was advantageous in making contacts with those individuals from the criminal justice system who worked the case. A second advantage is that it may alleviate potential problems of the research team being viewed as 'outsiders' making entree into the community much easier. Another advantage is that knowledge of the community is an asset in terms of accessing community understanding and perspective. A member of the research team knowing the history and idosynchracies of the community is an advantage to this type of research.

\section{THE LONG TERM IMPACT ON RESIDENTS OF ELKHART COUNTY}

It appears that from the beginning the largest paper in the county, The Elkhart Truth, supported Cosentino in all aspects related to the case. An 
editorial (Why Not? 1979, p. 4) reacting to Cosentino's subpoena of Henry Ford II and Lee Iacocca asked:

Why shouldn't these men come to explain to the grand jury what they can about Ford Pinto?... People here were shocked at the explosive crash which took the lives of three teen-age girls. Why shouldn't a local grand jury have the opportunity to question Ford executives ... What [sic, why] not let them know what local feelings are... Why not ask them here, where the accident happened?

The Elkhart Truth (Pinto Indictments, 1978, p. 4) also indicated their support following the indictment: "[w]e think the grand jury was right to make the indictments. Shipping its products throughout the country, the Ford Motor Co. must accept responsibility before local law." And when questions arose of the cost to the county of the prosecution there was this editorial (Pinto Prosecution, 1979, p. 4): "It's out of place to dwell on the cost. It's a question of responsibility to the law and to the public." Finally, even after Ford's acquittal, The Elkhart Truth (Pinto Trial Verdict, 1980, p. 4) provided support: "Even with the verdict as it stands, this has been a landmark case, because it showed the willingness, of the local community to involve itself in the question of the responsibility a manufacturer has for the products it sells..." This support by local media is important because it shows that at least initially, there were those in the community who viewed the case as being significant and having an effect on the community.

The other major newspaper from the county, The Goshen News, did not seem to think that the criminal case was necessary as an editorial following the indictment (Ford Indicted; So What? 1978, p. 4) stated that the "[d]esign of U.S. thirty-three ... also is a factor in the crash" and Cosentino's "[t]ime might be better spent trying local criminal cases." The editorial concluded by asking "If Cosentino wins this legal battle with Ford many months from now, what purpose will it serve? The general public found Ford 'guilty' in the Pinto case many months ago."

While the case may be considered very important to those in academia and law, the indictment was only named the fourth top story of the year in the state, according to Associated Press editors and news directors (Winter '78 State's Top news story). The stories appearing above the Pinto case were: (1) The blizzard of 1978, (2) The coal strike and accompanying energy shortage, and (3) the murder of four fast food workers in the Indianapolis area. 
Initially there appears to have been a strong community reaction to the accident. Richard Steinbronn (phone interview conducted on August 27, 1997), defense attorney for Ford and Elkhart resident at that time, stated that there was a lot of newspaper publicity and radio commentary as well as a "genuine horror reaction to the nature of the accident and the deaths of the girls". John Ulmer (interview conducted in Goshen Indiana on July $31,1997)$, prosecution attorney, also stated that the community was very interested and very upset that three girls had been killed. He also stated that people felt it was a tragedy and they couldn't figure why the car exploded. A reporter from Chicago (Byrne, 1978, p. 5) wrote that:

You can still feel the grief in this middle-sized, mid-American town a month after three joyous teen-aged girls died here in the fiery crash of their Ford Pinto. But you can detect another feeling-anguish that such promising young lives ended because someone may have knowingly built a car that could be a death trap.

A slightly different perspective was given by a local resident who commented that although it was shocking and received a lot of press, it was initially treated as just an unfortunate auto accident. According to a Ford dealer at the time in Elkhart County (phone interview conducted on August 1, 1997), the case was "[s]o well known that everyone [in the community] talked about it...", while a Ford dealer from St. Joseph County (phone interview conducted on August 1, 1997) felt that "People didn't talk that much about it" and that they didn't have an opinion that was "good, bad, or indifferent."

Steinbronn discussed the community's reaction to the prosecution of Ford as a mixed bag where some felt it was an appropriate action and others viewed it as "a gross overreaching by the prosecutor office"; however, there was no overwhelming sentiment one way or another. Elkhart Truth reporter David Schreiber (interview conducted in Elkhart Indiana on June 5, 1997) also commented on these divided attitudes. According to him, some were wondering why Cosentino was doing this, with speculations including aspirations for a higher office, such as governor, while others in the community agreed with the decision to go after Ford as they felt something was wrong with the three girls dying in an accident. An Elkhart resident also stated that a lot of people thought it was political and he recalls Cosentino taking flack for putting too much time into this case. Regardless of the public's specific feelings, $69 \%$ of 618 individuals polled in Elkhart and surrounding counties, at that time, stated that neither 
side could get a fair trial in Elkhart County (Ford Trial Out Of County, 1979).

Beginning in early 1980 , the Elkhart Truth, on at least two occasions, ran a Pinto Case Hotline (1/16/80, p. 9 and $1 / 25 / 80$, p. 13) which consisted of a list of questions about the case called in by readers. The paper then printed the questions and provided answers to the best of their ability. Questions included: "Why were the girls stopped on the highway?" "Why wasn't the driver of the van charged in connection with the accident?" "Wasn't it his fault?" "What gives Michael Cosentino, Elkhart County prosecutor, the right to use taxpayers' money to sue a corporation?" "Why isn't the engineer who has curbs placed along the highway charged with a crime. Isn't he as responsible as Ford?" "All cars are a potential death trap. Why is Ford being singled out?" "What is Cosentino getting out of this case?" As it can be seen, there were a number of ways to view the case and issues of responsibility according to members of the community.

Marvin Reicksecker (Interview conducted in Goshen Indiana on July 31, 1997), Elkhart County Coroner at the time, also recalled similar community feelings as he stated that were a lot of things being thought about: "Was the driver of the van on drugs?" "What were girls doing stopped on [sic]33," and "Why do we think we can prosecute the Ford Motor Company?" He adds "the community didn't feel that it was that necessary to go after the Ford Motor Company, they weren't that enraged by this", instead there was the question of driver judgment: "Who was really at fault?" In the area of personal responsibility there were, once again, mixed feelings in the community and Reicksecker emphasizes that there really was no community outrage. Similar sentiments are given by an individual who was working as a Ford dealer at the time, in St. Joseph County, and he commented that people thought "The accident could have been prevented by thoughtfulness on the part of the drivers." He also speculates that people were involved in this for financial reasons and were looking for a large settlement from Ford, when other factors such as improper vehicle handling, alcohol, and high speed, could have been contributing factors. One of the respondents to the survey also brought up the issue of financial gain and asked "[w]hy was Ford sued in the first place. Why not sue the state for not allowing a disabled car to get off the road. Why not sue the [driver of the van]. The answer, of course, is obvious ... you sue the organization that has the money whether or not it is the most guilty." 
Another perspective on responsibility came from a resident who also commented on the road where the accident occurred. This respondent stated that U.S. 33 has always been a dangerous stretch of road and was "notorious" for accidents and that much of the outcry at the time of the accident focused on the road. Interestingly, for members of the community, even prior to the Pinto accident U.S. 33 had been a frequent site of incidents. Yet another respondent to the survey noted that the case was about "A road ... built with curbs and no where[sic] for a stalled car to go". Two respondents also made references to the road being altered after the accident. When asked about the outcome of the case no respondents stated that the case had any discernible impact. Although respondents asserted that there was no impact from the case, several contradicted themselves when considering the role of the highway.

Ideas about Highway 33 appear to play a role in how people view the case's consequences on Elkhart County. Three survey respondents to the question of local impact of the case, listed the road being repaired. While local attorney John Ulmer, who worked with the prosecution during the Pinto case, stated that an impact on the community was the change [pull offs built] on U.S. 33. There were also three respondents to the survey who identified safety and public awareness as being an impact, of the trial, on the local community. Schrieber echo's this and states that the "consequence that is[sic] out there is a continuing realization that corporations have responsibility;" however, he adds that "[t]his isn't just from the Pinto trial." This hesitancy to link the Pinto case to a larger trend of corporate malfeasance was echoed by nearly all respondents and interviewees.

Among those who were involved with the trial there appear to be mixed sentiments as to whether or not the community remembers much of this incident. Prosecution attorney Terry Shewmaker (interview conducted in Elkhart Indiana on July 31, 1997) noted that while the community may still recall the case because of the strong feelings at the time, the passage of time has weakened those feelings. Assistant prosecutor John Ulmer also stated that the case is remembered by people who were there at the time and old enough but that the strong impressions of the case are gone. Reicksecker also believes that the community remembers some of the impact of the event and changes being made in the community, such as U.S. 33 being improved, but he speculates that it is a fading memory. On the other hand, head prosecutor Michael Cosentino (interview conducted in Elkhart Indiana on June 4, 1997) Elkhart Truth reporter David Schreiber 
and South Bend Tribune reporter Jeff Kurowski (phone interview conducted on August 1, 1997), all refer to the case as being "ancient history." Schreiber elaborates and states that there is no need to talk about it: " $[t]$ his case will be remembered the way other big news stories are remembered ... someone may make fleeting reference to it." He adds that it has become part of the oral tradition of the community. Former Judge Donald Jones (interview conducted in Elkhart Indiana on August 1, 1997) also stated that most people have forgotten about it. One of the individuals approached for an interview, was a local radio personality who has hosted a show on the major AM station in Elkhart for over twenty years. This show allows people to call in and discuss any issues of interest. $\mathrm{He}$ declined our interview request stating that it happened too long ago and he does not recall community feelings at the time.

There is evidence that people are forgetting specifics of the case as four of the eleven respondents incorrectly identified Ford as losing the case and three stated that the case forced Ford to recall and fix the Pintos, when in fact the recall began prior to the indictment. There were also three respondents who stated that the case had little to no impact on them and another three respondents described an impact on them being related specifically to Pintos: "I would not buy a Pinto, I'll never own a Pinto or ride in one, and I sold my Pinto."

A year after the author's visited the community, The Elkhart Truth ran a story on the twentieth anniversary of the accident recounting the events and subsequent trial (Schrieber, 1998). The article also discussed the importance of the case on holding corporations responsible for their actions and on the attention the case has received from those in academia. The fact that The Elkhart Truth ran the story, let alone on page one as the lead story, does show that there are those in the community who feel the case has importance today and that the residents of Elkhart County may still have an interest.

\section{FACTORS INFLUENCING COMMUNITY VICTIMIZATION}

While there are mixed signals regarding the impact this case may have had on the community, the indication from this research is that people are forgetting specifics of the Pinto case. The lack of concern among community members is intriguing considering the great importance of this case in 
the criminological literature. Despite the significance of the case in the field of criminology, it is possible that the case never had a dramatic impact on the community in the first place. It is possible that people were outraged but did not pay attention to the specifics of the case because of the state of the road or perceived actions of the drivers, which members of the community blamed for the accident. It is also possible that the significance of this case in terms of the local community is overstated among legal experts and criminologists. This is not to imply that the case is of lesser importance than generally believed, rather that from the vantage point of the community the case did not have a practical consequence on community members lives.

Further, it is important to note that the impact of the accident appears to be different than the impact of the legal decisions which surrounded the case. The accident was one tragedy among many in Northern Indiana at that time in 1978. However, the decision-making to seek an indictment and then later to proceed with a trial, regardless of the trial's outcome, was and remains a significant impact of the Pinto case. But, this impact is removed from the context of the local community, it is a far ranging legal impact.

Even though Ford was acquitted, the authors have used this incident as a case study to explore the concept of whether communities may suffer long term consequences from being indirectly 'victimized' by acts of corporate malfeasance and crime. Based on the findings of this study, a theory of the community as an indirect victim of corporate deviance has been formulated with ten factors identified which may influence the long term 'victimization' of a community. These will be presented in general terms, but illustrated through how they are applicable to the Pinto case.

\section{The Passage of Time}

With the twentieth anniversary approaching, of the Pinto trial, a simple explanation is that people have forgotten about the incident. There was some follow-up done by the media one year after the trial (Cosentino still sees victory in Pinto case) and on the fifth year anniversary (Stoner). This indicates some interest in the trial at those time points, which has seemingly diminished since the then. Had a community survey been done at these times, there still may have been a visible effect on the community. 


\section{Outcome of the Trial}

In this incident Ford was acquitted; however, if there would have been a conviction, the community may have felt outrage and would have had a clear target to blame. Kurowski, the South Bend Tribune reporter on the Pinto case, commented that because of an acquittal the impact and memory of the case diminishes. There are a variety of reasons why the public does not remember the case and why it may have failed to have much impact beyond the fact that the people were saddened by the deaths of three girls. Some of these factors may include: the public perception of corporate wrong-doing as less serious than street crime, the odd circumstances of the accident, the significance of a large manufacturing major employer to Elkhart county, the public image of the Ford Motor Company, the frequency of accidents along highway 33 , and the small number of immediate victims in the accident. In other words, the Pinto case, to the local community, was an accident not an example of corporate crime. Thus, members of the community did not feel personally or collectively victimized by Ford and are less willing to hold Ford accountable. This does not reflect on the seriousness of the case or its consequences, just the community's perception of the case.

\section{Alternative Sources of Blame}

Were there other possible explanations which could have contributed to, or caused, the incident? In this case potential blame may have been placed on driver error or the design of the road. It is also possible that blame may have been placed on the 'victims.' These factors could reduce the long term impact on a community because a corporation is not seen as causing the incident, the degree of guilt associated with the corporation is in question. At this time Ford was facing numerous law suits based on the Pinto and part of the public may have felt that the driver and passengers had made a choice to engage in risky behavior, similar to arguments made regarding smokers. These factors could reduce the long term impact on a community because a corporation is not seen as causing the incident. In the Pinto case, the community may not have seen itself as victimized by the Ford Motor Company because they were not perceived as the primary causal agent. If other factors may have contributed, or caused an incident, blame may be placed on these other factors, rather than on the corporation. 


\section{Number of Victims}

The authors believe that size of incident(s) is directly proportional to public outrage. In the Pinto case three young girls were killed; however, as previously discussed, people feel that it was a tragedy, but accidents happen frequently. Because of this, and the relatively small number of victims, community outrage may have been short lived or at low levels. Had there been a larger number of victims, making it unique from the typical accident, it may have resulted in more anger within the community. If community anger is low than it is possible that the outrage is difficult to measure.

\section{Community Environment}

A community's perception and anger about potential corporate malfeasance is also influenced by the conditions within the community. Larger political, economic, and cultural trends may shape community attention toward a trial. There was some indication that those in Elkhart County were distracted by other factors at the time, specifically the economy. According to Kurowski, in early 1980 Elkhart was in a depression second only in the state to the city of Anderson. One of the respondents stated that he had a passing interest of the case because of television coverage, but did not follow the trial closely because the "economy [was] kind of taking a dump around here." The respondent goes on to state that the "[economy] was at the forefront of a lot of peoples concerns and worries back then ..." Facing these types of "distractions," those in the community may have felt less outrage as there were more "important" concerns affecting them directly.

\section{Presentation of the Case}

It is important to note that the nature of the discourse about and within a trial may be a significant factors related to perception of a trial. In the Pinto case, there may have been a lack of interest in the trial for residents because it involved a lot of technical dialog related to automobile manufacturing. The defense's decision to not contest that the girls died because of fire exposure and smoke inhalation allowed them to remove the more compelling, and possibly damaging, components of the case to 
Ford's public image. The case, because of this decision, was not exciting or sensational, which may have resulted in a loss of public interest in the trial.

Also while the Pinto case was widely reported in newsprint the coverage was not consistent or intense. Today the penetration of media, especially television, results in different understandings and recollections of high profile court cases. The perceived impact of the Pinto case could have been much greater if the trial had been televised or if the media had descended upon it akin to recent high profile cases, e.g., California v. O.J. Simpson.

\section{Location of the Trial}

Another factor affecting public outrage is based on where a trial takes place. If a trial is moved, it is possible that public concern may be muted. According to one Elkhart resident, even though the Pinto case got a lot of publicity, because of the change of venue the immediate Elkhart community was removed from the day-to-day trial. This may not have a significant impact today due to the expanded use of technology and some court cases being carried live on television. This shift in location also had a tremendous impact on how the trial itself was conducted. Being granted a change of venue from an urban city to a rural city may have allowed Ford to present its side of the case in a way that was conducive to an acquittal.

\section{Composition of the Community}

Of course, the demographics of a community has an impact on a case. One Elkhart resident commented that there may have been little impact because there is no real 'community.' In other words, no strong community bond or "spirit" equals little or no community uproar regarding reaction to the Pinto case. The respondent goes on to discuss how Filkhart is a transient community because of the nature of employment: this results in a "strange" population of community members who have no strong sense of connection to each other. Community members in Elkhart include an isolated racial minority population, a strong Appalachian influence, a small very wealthy group, some poor, no solid middle class, and a conservative and self contained Amish-Mennonite population. 


\section{Relationship between the Victims and the Community}

Generally, if the victims in a case are not seen as fully participating community members, the town may not react collectively to the incident. Membership, in other words, influences the recollection and perception of a case. None of the three victims of the Pinto case were from Elkhart County and therefore were possibly viewed as 'outsiders.' This idea was also echoed by Schrieber (see Cullen et al., 1987, p. 179). Even though the accident occurred in Elkhart County, and the prosecution originated there, the community may not have seen itself as a victim because the girls were from outside the area.

\section{Relationship between the Corporation and the Community/Perceptions of Corporations}

To many in the local community Ford was more of an abstraction than a presence in their lives. In the Pinto case the Ford Motor Company was located in another state and may therefore be viewed as an abstract entity. If the offending corporation is a local one it may seem more "real" rather than a distant organization. Also, a case against a major employer of workers in a town may generate strong interest, while a case directed at a little known company may not. The fact that Ford was removed from their day-to-day lives allowed members of the community to distance themselves from the accident and from the trial. The corporation appears more to have been a removed concept to many. In addition, it is considered un-American to question the organization of corporations and the American economy. Thus, the difficult question of corporate misdeeds are more likely conceptualized as the activities of individuals rather than the organization.

\section{CONCLUSIONS}

While the State of Indiana v. Ford Motor Company is considered a watershed legal moment, for the citizens of Elkhart County the case was not significant in changing their lives. This is not to suggest that the citizens held no strong opinions of the incident or the litigation. Several community members referred to the crash and resulting fire as an "unfortunate incident" and the prosecution of Ford as a natural outgrowth of the prosecutor "just doing his job." There appears, from this research, to be no 
resentment against Ford from community members surveyed or from anyone on the prosecution team. It should be noted that Ford's public relation theme of "Quality is Job one," has been successful. Ford is consistently ranked as one of the most trusted American corporations. The long term impact of the case on Ford appears to be minimal.

It remains to be established whether this perspective on corporate crime and victimization (or the lack of a perception or experience of it) occurs in other communities. In general, this case has provided the authors the opportunity to begin examining whether communities suffer long term consequences from indirect victimization of corporate crime. This is an area worthy of future study. Future research will also provide the opportunity to examine the interrelationships between the ten factors we have identified here. For example, does the existence of multiple sources that can be blamed for an incident reduce the likelihood that a community experiences indirect victimization by a corporation regardless of the number of victims or trial outcome? The ten factors discussed in the previous section may be developed into hypotheses to further explore this issue. The authors feel that other communities need to be studied where there were variations in these factors, perhaps most importantly, communities where there was clear guilt, or wrongdoing resulting from corporate actionsespecially where corporations were convicted. By engaging in research examining different communities that vary on the levels of crime/wrongdoing, perceived victims, outcome of trials, and media attention, we believe that assessments of community victimization will be enhanced.

\section{ACKNOWLEDGEMENT}

This project was funded by a Morehead State University Faculty Research Grant. The authors wish to thank the following for their assistance in this project: Peter Yeager, David Rudy, Edward Reeves, and all of the individuals who took time to discuss the Pinto Case with the authors. An earlier version of this paper was presented at the annual meeting of the American Society of Criminology, San Diego, CA, November 1997.

\section{References}

Albanese, Jay S. (1984). Love canal six years later: The legal legacy. Federal Probation, $48(2), 53-8$. 
Albanese, Jay S. (1995). White collar crime in America. Englewood Cliffs, NJ: Prentice Hall. Associated Press. Winter '78 State's Top news story.

Aulette, Judy Root and Raymond Michalowski. (1995). Fire in Hamlet: A case study of state-corporate crime. In Gilbert Geis, Robert F. Meier, and Lawrence M. Salinger (Eds.) White-Collar Crime: Classic and Contemporary Views, 3rd ed., (pp. 166-190). New York: The Free Press.

Ayers Jr., Kenneth A. and James Frank. (1987). "Deciding to prosecute white collar crime: A national survey of state attorneys general." Justice Quarterly, 4(3), 425-439.

Benson, Michael L., Francis T. Cullen and William J. Maakestan. (1990). "Local prosecutors and corporate crime." Crime \& Delinquency, 36(3), 356-372.

Benson, Michael L., William J. Maakestan, Francis T. Cullen and Gilbert Geis. (1988). "District attorneys and corporate crime: Surveying the prosecutorial gatekeepers." Criminology, 26(3), 505-518.

Birsch, Douglas and John H. Fielder (Eds.) (1994). The Ford Pinto Case: A Study in Applied Ethics, Business, and Technology. Albany, NY: State University of New York Press.

Burt, Martha R. (1997). The effects of victimization: What we know, what is missing, and implications for assuring the impact and effectiveness of VOCA. A background paper in A Report of the victims needs strategic planing meeting, March 10, 1997, Sponsored by the National Institute of Justice and Office for Victims of Crime.

Byrne, Dennis. (1978, September 17). The Pinto, the girls, the anger. Chicago Sun-Times, p. 5,50 .

Clark, Glenn A. (1979). Corporate homicide: A new assault on corporate decision-making, Notre Dame Lawyer, 54(5), 911-924.

Clinard, Marshall B. (1990). Corporate Corruption. New York: Praeger.

Cosentino still sees victory in Pinto case. (3/2/81). The Elkhart Truth.

Cullen, Francis T., William J. Maakestan and Gray Cavender. (1987). Corporate Crime Under Attack: The Ford Pinto Case and Beyond. Cincinnati, $\mathrm{OH}$ : Anderson.

Fischel, Daniel R. and Alan O. Sykes. (1996). "Corporate Crime." The Journal of Legal Studies, 25(June), 319-349.

Ford Indicted; So What? The Goshen News, 9/14/78, p. 4.

Ford Trial Out Of County, The Goshen News, 4/11/79.

Frank, Nancy K. and Michael J. Lynch. (1992). Corporate Crime Corporate Violence. New York, NY: Harrow and Heston.

Geis, Gilbert. (1995). The heavy electrical equipment antitrust cases of 1961. In Gilbert Geis, Robert F. Meier, and Lawrence M. Salinger (Eds.) White-Collar Crime: Classic and Contemporary Views, 3rd ed., (pp. 151-165). New York: The Free Press.

Geis, Gilbert. (1975). Victimization patters in white-collar crime. In Israel Drapkin and Emilio Viano (Eds.) Victimology: A New Focus-Vol. 5, (pp. 89-105). Lexington, MA: Lexington Books.

Geis, Gilbert, Robert F. Meier and Lawrence M. Salinger (Eds.). (1995). White-Collar Crime: Classic and Contemporary Views, 3rd ed. New York: The Free Press.

Green, Gary S. (1990). Occupational Crime. Chicago: Nelson-Hall.

Gulotta, Gugliemlo. (1985). Collective Victimization. Victimology: An International Journal $10(1-4), 710-723$.

Hills, Stuart L. (Ed.) (1987). Corporate Violence. Totowa, NJ: Rowman \& Littlefield.

Lansing, Paul and Donald Hatfield. (1985). "Corporate Control Through the Criminal System-An Alternative Proposal." Journal of Business Ethics, 4, 409-414.

Lee, Raymond M. (1993). Doing research on sensitive topics. Newbury Park, CA: Sage.

Lynch, James P. (1997). Who are the Victims? A background paper in A Report of the victims needs strategic planing meeting, March 10,1997, Sponsored by the National Institute of Justice and Office for Victims of Crime.

Makestan, William J. (1987, May). "Redefining Corporate Crime." Multinational Monitor, 7-9. 
Meier, Robert F. and James F. Short Jr. (1995). The Consequences of White-Collar Crime. In Gilbert Geis, Robert F. Meier, and Lawrence M. Salinger (Eds.) White-Collar Crime: Classic and Contemporary Views, 3rd ed., (pp. 151-165). New York: The Free Press.

Moore, Elizabeth and Michael Mills. (1990). The Neglected Victims and Unexamined Costs of White-Collar Crime. Crime \& Delinquency, 36(3), 408-418.

Meyer, Peter B. (1981). Communities as victims of corporate crimes. In Burt Galaway and Joe Huson (Eds.). Perspectives on crime victims (pp. 33-43). St. Louis: The C.V. Mosby Company.

Nagel, Ilene H. and John L. Hagan. (1982). "The Sentencing of White-Collar Criminals in Federal Courts: A Socio-Legal Exploration of Disparity." Michigan Law Review, 80(7), 1427-1465.

Pinto Case Hotline, Elkhart Truth, 1/16/80, p. 9.

Pinto Case Hotline, Elkhart Truth, 1/25/80, p. 13.

Pinto Indictments, The Elkhart truth, 9/14/78, p. 4.

Pinto Prosecution, Elkhart Truth, 5/3/79, p. 4.

Pinto Trial Verdict, Elkhart Truth, 3/14/80, p. 4.

Podgor, Ellen S. (1994). Corporate and White Collar Crime: Simplifying the Ambiguous. American Criminal Law Review, 31(3), 391-401.

Schreiber, David. (1980, March 14). Pinto verdict-Questions remain. The Elkhart Truth.

Schreiber, David. (1998, August 10). Crash's historic impact. The Elkhart Truth, p. 1.

Shover, Neil, Greer Litton Fox and Michael Mills. (1994). Long-term consequences of victimization by white-collar crime. Justice Quarterly, 11(1), 75-98.

Stitt, B. Grant and David J. Giacopassi. (1995). "Assessing Victimization from Corporate Harms." in Michael B. Blankenship (Ed.) Understanding Corporate Criminality (pp. 57-83). New York, NY: Garland.

Stoner, Andrew. 5 years later, lawyers share mutual respect: Ford trial. South Bend Tribune.

Strobel, Lee Patrick. (1980). Reckless Homicide? Ford's Pinto Trial. South Bend, IN: and books.

Strobel, Lee. (1980, March 14). Pinto jury acquits Ford. Chicago Tribune.

Swigert, Victoria Lynn and Ronald A. Farrell. (1980-81). Corporate homicide: Definitional processes in the creation of deviance. Law and Society Review, 15(1), 161-182.

Szockyj, Elizabeth and James G. Fox (Eds). (1996). Corporate victimization of women. Boston: Northeastern University Press.

Tigar, Michael E. (1990). "It Does the Crime but not the Time: Corporate Criminal Liability in Federal Law." American Journal of Criminal Law, 17(3), 211-234.

Welty, William M. (1982, September). The Ford Pinto. Case Studies (no. 9)-Center for Applied Research, The Lubin Graduate School of Business, Pace University. New York, NY: Pace \& Pace, Ltd.

Wheeler, Malcolm E. (1981, Fall). "Product Liability, Civil or Criminal-The Pinto Litigation." Forum, 250-265.

Why Not?, The Elkhart Truth, 9/7/78, p. 4. 